\title{
PERAN SELF-COMPASSION DAN SPIRITUALITAS TERHADAP DEPRESI PADA IBU HAMIL
}

\author{
Alfira Chairunnisa $^{1}$ \& Endang Fourianalistyawati ${ }^{2}$ \\ Fakultas Psikologi Universitas YARSI, Jln. Cempaka Putih Timur, Jakarta 10510, Indonesia \\ Korespondensi: \\ 'e-mail: alfirac@gmail.com; ${ }^{2} e$-mail: endangfouriana@gmail.com
}

\begin{abstract}
Pregnancy is a significant event that causes changes both physically and psychologically among pregnant women. Hence, it can trigger symptomps of depression during pregnancy. Previous studies have shown that self-compassion significantly correlated with depression, as well as spirituality. Therefore, the purpose of this study was to examine the role of self-compassion and spirituality toward depression among pregnant women simultaneously. The sample of this study was pregnant women who had completed Edinburgh Postnatal Depression Scale (EPDS), Self-Compassion Scale (SCS), and Daily Spiritual Experience Scale (DSES) $(n=125)$. The result of multiple regression analysis showed that self-compassion and spirituality have significant roles in predicting depression among pregnant women simultaneously. A higher score of self-compassion could predict a lower score of depression, even when the score of spirituality was being controlled. The selfjudgement and perception of transcendent events dimensions have significant contributions toward depression among pregnant women.
\end{abstract}

Article history:

Received 24 January 2018

Received in revised form 17 Oktober 2018

Accepted 6 March 2019

Available online 8 April 2019

\section{Keywords:}

depression;

pregnant women;

self-compassion;

spirituality

\begin{abstract}
Abstrak - Kehamilan merupakan peristiwa penting yang menyebabkan adanya perubahan fisik dan psikologis pada ibu hamil, sehingga dapat menimbulkan gejala depresi selama masa kehamilan. Penelitian sebelumnya menemukan bahwa self-compassion berkorelasi negatif secara signifikan dengan depresi, begitu pula pada spiritualitas. Oleh karena itu, penelitian ini bertujuan untuk menguji peran self-compassion dan spiritualitas secara bersama-sama terhadap depresi pada ibu hamil. Penelitian ini melibatkan 125 ibu hamil yang melengkapi kuesioner Edinburgh Posnatal Depression Scale (EPDS), SelfCompassion Scale (SCS), dan Daily Spiritual Experience Scale (DSES). Hasil uji regresi ganda menunjukkan bahwa self-compassion dan spiritualitas memiliki peran yang signifikan secara bersama-sama dalam memprediksi depresi pada ibu hamil. Ibu hamil dengan skor self-compassion yang lebih tinggi mampu memprediksi skor depresi yang lebih rendah meskipun skor spiritualitasnya dibuat tetap, dan sebaliknya. Aspek selfjudgement dan persepsi terhadap peristiwa transenden diketahui memiliki kontribusi yang signifikan terhadap depresi pada ibu hamil. Hasil penelitian tersebut diharapkan dapat memberikan kontribusi dalam mengatasi prevalensi depresi pada ibu hamil yang semakin meningkat.
\end{abstract}

Kata Kunci: depresi; ibu hamil; self-compassion; spiritualitas 


\section{PENDAHULUAN}

Kehamilan merupakan salah satu peristiwa yang dilalui setiap perempuan untuk menjadi seorang ibu. Peristiwa tersebut umumnya dialami selama sembilan bulan atau sekitar 38 hingga 40 minggu. Selama masa kehamilan hingga masa kelahiran, terdapat berbagai perubahan hormon yang dialami ibu, yaitu meningkatnya hormon estrogen yang bertanggung jawab terhadap perkembangan janin, transfer nutrisi, serta pembentukan pembuluh darah yang berlebih pada uterus dan hormon progesteron yang menyebabkan adanya pelunakan ligamen dan pelonggaran sendi-sendi yang terdapat di bagian tubuh serta peningkatan ukuran struktur internal, seperti ureter maupun ukuran rahim (Krucik, 2012).

Peningkatan hormon-hormon tersebut dapat menyebabkan perubahan pada berbagai aspek fisiologis ibu hamil. Kebanyakan ibu hamil umumnya mengalami pembengkakan pada beberapa daerah tubuh, kerontokan atau pertumbuhan rambut di daerah tertentu, kerusakan pada kuku, pembesaran payudara, gangguan penglihatan ringan, rasa hambar pada indra perasa, serta meningkatnya kepekaan pada indra pencium (Brown \& Toma, 1986; Dinn, Harris, \& Marcus, 2003; Krucik, 2012). Selain itu, ibu hamil seringkali mengalami perubahan pada kulit, seperti kulit wajah yang menggelap serta timbulnya stretch marks (guratan peregangan) dan bintik hitam pada kulit (Tunzi \& Gray, 2007). Terdapat pula gangguan pada sistem sirkulasi darah maupun sistem pernafasan yang dapat dialami ibu hamil, seperti meningkatnya tekanan darah dan detak jantung, timbulnya rasa pusing, serta terjadinya sesak napas dan dehidrasi (Krucik, 2012)

Meningkatnya hormon estrogen dan progesteron juga memengaruhi aspek psikologis ibu hamil. Penelitian terdahulu menemukan bahwa terdapat beberapa gangguan emosi yang umumnya dialami oleh ibu hamil selama masa kehamilan dan pasca kelahiran. Gangguan emosi tersebut meliputi kemarahan, ketegangan, gugup, kecemasan patologis, dan gejala depresi (Affonso dkk., 1992). Hal tersebut dapat disebabkan oleh adanya perubahan hormon yang dialami, sehingga dapat meningkatkan kemungkinan ibu hamil menghadapi situasi kehidupan dengan perasaan stres atau cemas (Ross, Sellers, Evans, \& Romach, 2004). Perasaan stres atau cemas tersebut dapat menimbulkan adanya depresi selama masa kehamilan.

Gejala depresi selama masa kehamilan banyak ditemui pada ibu hamil secara menyeluruh. Prevalensi gejala tersebut diperkirakan mencapai 6.5 persen hingga 12.9 persen di seluruh dunia (Gavin dkk., 2005) dengan perkiraan sebanyak 7.4 persen ibu hamil yang mengalaminya selama trimester pertama, 12.8 persen selama trimester kedua, dan 12 selama selama trimester terakhir 
(Bennet, Einarson, Taddio, Koren, \& Einarson, 2004). Tidak terdapat angka yang pasti mengenai prevalensi depresi yang dialami oleh ibu hamil di Indonesia saat ini. Namun, gejala depresi lebih banyak ditemui pada ibu hamil di Asia dibandingkan dengan negara-negara barat lainnya. Hal tersebut disebabkan oleh adanya faktor kehamilan di luar pernikahan, konflik dengan ibu mertua, serta ketidakpuasan terhadap jenis kelamin bayi yang turut memicu timbulnya depresi (Roomruangwong \& Epperson, 2011). Selain itu, gejala depresi lebih banyak ditemui pada masa kehamilan dibandingkan dengan masa pasca kelahiran (Evans, Heron, Francomb, Oke, \& Golding, 2001; Hayes, Muller, \& Bradley, 2001).

Adanya stigma terkait depresi dan kesenjangan antara harapan masa kehamilan yang menyenangkan dengan perasaan sedih yang dialami dapat membuat ibu hamil tidak menceritakan pengalaman depresinya kepada orang lain (Marcus, 2009). Namun, depresi selama masa kehamilan dapat menyebabkan beberapa dampak negatif jika tidak mendapatkan penanganan secara tepat. Depresi pada ibu hamil berkorelasi positif dengan terganggunya keberfungsian ibu (Birndorf, Madden, Portera, \& Leon, 2001), rendahnya berat badan bayi ketika lahir, kelahiran secara prematur (Grote dkk., 2010), serta resiko mengalami depresi postpartum (Josefsson, Berg, Nordin, \& Sydsjö, 2001). Luoma dkk. (2001) menemukan bahwa depresi pada ibu hamil dapat memengaruhi kesehatan dan penyesuaian anak dalam jangka panjang, di mana pengalaman depresi selama masa kehamilan merupakan faktor prediktor terkuat.

Terdapat beberapa faktor psikologis yang berkorelasi dengan rendahnya tingkat depresi pada ibu hamil, seperti peristiwa kehidupan, kualitas pernikahan, dan dukungan sosial (O’Hara, 1986; Karacam \& Ancel, 2009). Penelitian Pajulo, Savonlahti, Sourander, Helenius, dan Piha (2001) menemukan bahwa dukungan yang diberikan oleh pasangan berkorelasi dengan rendahnya tingkat depresi selama masa kehamilan. Sebaliknya, kesulitan dalam hubungan pasangan berkorelasi dengan tingkat depresi ibu hamil yang lebih tinggi. Kesulitan dalam hubungan kerabat maupun pertemanan juga berkontribusi terhadap peningkatan depresi, namun hanya penerimaan dukungan dari pasangan maupun orangtua yang dapat memprediksi rendahnya tingkat depresi selama masa kehamilan (Kroelinger \& Oths, 2000).

Meskipun demikian, tidak selamanya ibu hamil dapat bergantung pada orang lain untuk mendapatkan dukungan sosial karena terdapat faktor psikologis yang berasal dari dalam diri ibu hamil (faktor internal) dan berkorelasi dengan rendahnya tingkat depresi. Faktor internal tersebut terdiri dari strategi coping, resiliensi, sifat kepribadian, keberhargaan diri, self-compassion, dan spiritualitas (Dumont \& Provost, 1999; Felder, Lemon, Shea, Kripke, \& Dimidjian, 2016; Mann, 
McKeown, Bacon, Vesselinov, \& Bush, 2007). Ibu hamil yang sedang mengalami penyesuaian terhadap kehamilannya cenderung menunjukkan beberapa gejala emosi negatif (Affonso dkk., 1992), sehingga diperlukan sikap yang lebih positif terhadap diri sendiri dalam menangani gejala tersebut. Sikap positif tersebut dapat berupa sikap optimis selama masa transisi kehamilan, regulasi diri terhadap gangguan kesehatan yang dialami, serta belas kasih terhadap diri sendiri atau yang biasa disebut sebagai self-compassion (Carver \& Gaines, 1987; Rasmussen, Wrosch, Scheier, \& Carver, 2006; Neff, 2003a). Akan tetapi, sikap yang paling berkaitan dengan penanganan emosi negatif adalah self-compassion.

Self-compassion merupakan suatu perasaan terbuka dan tergugah terhadap kesulitan yang sedang dialami, perasaan peduli dan penuh kebaikan terhadap diri sendiri, memahami ketidakmampuan diri dan kegagalan yang dialami, serta menyadari bahwa pengalaman diri merupakan bagian dari pengalaman kebanyakan orang secara umum (Neff, 2003a). Penelitian sebelumnya menunjukkan bahwa self-compassion berkorelasi negatif secara signifikan dengan depresi pada ibu hamil (Felder, Lemon, Shea, Kripke, \& Dimidjian, 2016). Dengan kata lain, ibu hamil yang memiliki self-compassion tinggi akan memiliki tingkat depresi yang rendah, begitu pula sebaliknya. Telah ditemukan pula bahwa self-compassion dapat memperkecil kemungkinan seseorang untuk mengalami depresi, baik pada masa kehamilan maupun sepanjang masa kehidupan (Bento dkk., 2016).

Pada penelitan-penelitian sebelumnya, self-compassion telah banyak digunakan untuk memprediksi aspek kesehatan mental. Self-compassion memiliki korelasi positif dengan beberapa keberfungsian psikologis yang positif, seperti kebahagiaan, optimisme, sikap positif, kebijaksanaan, inisiatif personal, keingintahuan, serta trait agreeableness, extroversion, dan conscientiousness (Neff, Rude, \& Kirkpatrick, 2007). Selain itu, terdapat pula korelasi antara peningkatan kesehatan mental dengan meningkatnya self-compassion (Gilbert \& Procter, 2006). Sebaliknya, selfcompassion memiliki korelasi negatif dengan kritik diri, depresi, kecemasan, perenungan, supresi, dan perfeksionisme neurotik (Neff, 2003b; Leary, Tate, Adams, Allen, \& Hancock, 2007). Lebih jelasnya, Leary dkk. (2007) menambahkan bahwa self-compassion dapat meredam reaksi seseorang terhadap peristiwa yang tidak menyenangkan, sehingga ia tidak terlarut dalam emosi-emosi negatif yang dirasakan. Dengan demikian, self-compassion diprediksi dapat mengurangi kemungkinan seseorang untuk mengalami depresi.

Terdapat faktor psikologis lainnya yang juga berasal dari dalam diri dan memiliki keterkaitan terhadap depresi selama masa kehamilan, yaitu spiritualitas. Seperti yang telah 
diuraikan sebelumnya, ibu hamil cenderung membutuhkan dukungan eksternal dalam menjalani masa kehamilannya (Kroelinger \& Oths, 2000; Pajulo, Savonlahti, Sourander, Helenius, \& Piha, 2001) yang dapat dipenuhi melalui spiritualitas. Spiritualitas merupakan persepsi seseorang mengenai keberadaan dan keterlibatan hal-hal yang bersifat transenden dalam kehidupannya seharihari, di mana hal-hal tersebut berada di luar kesanggupan manusia, seperti Tuhan (Underwood \& Teresi, 2002). Spiritualitas dapat pula didefinisikan sebagai kesadaran mengenai kesatuan alam semesta dan keterkaitan individu satu sama lain dengan alam semesta (Lerner, dalam King, 2003). Definisi tersebut menunjukkan bahwa spiritualitas tidak hanya berkaitan dengan hal-hal yang bersifat transenden, namun mencakup pula perasaan terhubung dengan orang lain.

Pada penelitian sebelumnya, diketahui bahwa spiritualitas memiliki keterkaitan dengan depresi dan masa kehamilan. Mann dkk. (2007) menemukan bahwa spiritualitas berkorelasi negatif dengan depresi yang dialami ibu selama masa kehamilan, khususnya ketika tidak terdapat dukungan sosial. Spiritualitas juga berkorelasi dengan kesehatan mental yang lebih baik serta rendahnya tingkat depresi, kecemasan, dan penyalahgunaan obat-obatan (Nelson dkk., 2009; Koenig, 2010). Jesse, Schoneboom, dan Blanchard (2007) menyatakan bahwa spiritualitas dimaknai sebagai petunjuk dan bantuan, memberikan perlindungan dan berkah, memberikan jalan untuk berkomunikasi dengan Tuhan, memberikan kekuatan dan keyakinan, jawaban dari berbagai pilihan sulit, serta memengaruhi kehamilan secara positif. Pemaknaan tersebut termasuk dalam salah satu teknik spiritual coping, yaitu penggunaan keyakinan spiritual yang dimiliki dalam menanggulangi peristiwa yang dialami (Koenig, 2010). Penanggulangan tersebut diperkirakan turut berkontribusi dalam mengurangi tekanan emosional (Boscaglia, Clarke, Jobling, \& Quinn, 2005). Oleh karena itu, spiritualitas diprediksi dapat memengaruhi depresi pada ibu hamil.

Berdasarkan hasil penelitian mengenai depresi pada ibu hamil yang telah diuraikan sebelumnya, telah ditemukan bahwa terdapat hubungan yang bersifat negatif antara depresi selama masa kehamilan dengan self-compassion (Felder dkk., 2016) maupun dengan spiritualitas (Mann dkk., 2007). Dengan demikian, terdapat kemungkinan bahwa self-compassion dan spiritualitas memiliki peranan terhadap penurunan tingkat depresi pada ibu hamil. Akan tetapi, belum terdapat penelitian yang melihat pola interaksi antara self-compassion dan spiritualitas terhadap depresi pada ibu hamil. Penelitian mengenai hal tersebut penting untuk diteliti mengingat adanya prevalensi depresi pada ibu hamil secara global yang cukup tinggi (Bennet, Einarson, Taddio, Koren, \& Einarson, 2004; Gavin dkk., 2005). Selain itu, depresi pada ibu hamil dapat menyebabkan dampak 
negatif bagi ibu hamil itu sendiri maupun calon anak dalam jangka panjang (Birndorf dkk., 2001; Grote dkk., 2010; Josefsson dkk., 2001; Luoma dkk., 2001).

Oleh karena itu, peneliti ingin melengkapi kekurangan-kekurangan tersebut dengan melakukan penelitian mengenai peran self-compassion dan spiritualitas terhadap depresi pada ibu hamil. Selain itu, peneliti juga melakukan pengujian terhadap aspek-aspek self-compassion dan spiritualitas yang berperan terhadap depresi pada ibu hamil. Hasil penelitian ini diharapkan dapat memperkaya sumber literatur yang ada dan dapat dijadikan rujukan dalam mengatasi permasalahan depresi pada ibu hamil. Karakteristik sampel yang digunakan dalam penelitian ini adalah ibu hamil yang berusia 18 tahun atau lebih dan memiliki tempat tinggal di Jakarta, Bogor, Depok, Tangerang, atau Bekasi.

\section{Self-Compassion}

Compassion melibatkan perasaan tersentuh akan penderitaan orang lain, menyadari rasa sakit seseorang tanpa menghindari atau terputus, sehingga dapat meringankan penderitaan tersebut melalui kebaikan terhadap orang lain (Wispe, 1991). Oleh karena itu, self-compassion merupakan aplikasi dari definisi tersebut. Neff (2003a) mendefinisikan self-compassion sebagai suatu perasaan terbuka dan tergugah terhadap kesulitan yang sedang dialami, perasaan peduli dan penuh kebaikan terhadap diri sendiri, memahami ketidakmampuan diri dan kegagalan yang dialami, serta menyadari bahwa pengalaman diri merupakan bagian dari pengalaman kebanyakan orang secara umum.

Menurut Neff (2003a), self-compassion terbagi menjadi tiga aspek dasar yang dapat saling memengaruhi satu sama lain, yaitu self-kindness, common humanity, dan mindfulness. Self-kindness didefinisikan sebagai memberikan kebaikan dan pemahaman terhadap diri sendiri, khususnya terhadap ketidakmampuan diri atau ketika mengalami kegagalan. Oleh karena itu, aspek ini secara konsep bertolak belakang dengan self-judgement, yaitu mengadili dan mengkritik diri sendiri secara berlebihan. Ibu hamil yang memiliki self-kindness diprediksi cenderung menerima keadaan yang dialaminya selama masa kehamilan. Sebaliknya, ibu hamil yang memiliki self-judgement tinggi cenderung menyalahkan dirinya secara berlebihan atas kondisi yang dialaminya selama masa kehamilan.

Common humanity didefinisikan sebagai melihat pengalaman diri sebagai bagian dari kehidupan manusia yang lebih luas. Oleh karena itu, aspek ini bertolak belakang dengan isolation, yang memandang pengalaman diri secara terpisah dengan pengalaman orang lain. Ibu hamil yang memiliki common humanity yang tinggi diprediksi cenderung memandang pengalaman selama 
masa kehamilannya sebagai hal yang umumnya dialami oleh kebanyakan ibu hamil lainnya. Sebaliknya, ibu hamil yang memiliki isolation tinggi cenderung memandang pengalaman dirinya sebagai sesuatu yang hanya dialami oleh dirinya saja, sedangkan orang lain memiliki kondisi yang lebih baik dari kondisi yang dialaminya (Neff, 2003a).

Aspek ketiga, yaitu mindfulness, didefinisikan sebagai memandang pikiran dan perasaan diri yang menyakitkan dalam keadaan kesadaran yang seimbang. Oleh karena itu, aspek ini secara konsep bertolak belakang dengan overidentification yang cenderung terlarut dalam pikiran dan perasaan negatif yang dimilikinya. Ibu hamil dengan mindfulness tinggi diprediksi cenderung dapat menjaga keadaan pikirannya secara seimbang. Sedangkan, ibu hamil dengan overidentification tinggi cenderung terlarut dalam emosi-emosi negatif yang dimilikinya selama masa kehamilan (Neff, 2003a).

\section{Spiritualitas}

Menurut Underwood dan Teresi (2002), spiritualitas didefinisikan sebagai persepsi seseorang mengenai keberadaan dan keterlibatan hal-hal yang bersifat transenden dalam kehidupannya sehari-hari. Goodenough (2001) menyatakan bahwa konsep transenden yang terdapat pada spiritualitas dapat dideskripsikan, baik secara vertikal maupun horizontal. Definisi tersebut sejalan dengan model spiritualitas yang telah diungkapkan oleh Ellison pada tahun 1983. Ia menggunakan pendekatan vertikal-horizontal, di mana kedua dimensi tersebut saling berhubungan dan tidak terpisahkan. Dimensi vertikal mengacu kepada hubungan seseorang dengan Tuhan atau hal-hal lain yang melampaui dirinya sendiri dan merupakan sumber dari nilai tertinggi, serta memberikan petunjuk kepada hidupnya. Dimensi horizontal mengacu kepada jenis dan kualitas hubungan seseorang dengan dirinya sendiri dan orang lain, kesejahteraan dalam hubungan tersebut, dan makna dari tujuan dan kepuasan hidup seseorang.

Spiritualitas bukan merupakan suatu atribusi yang dapat hadir maupun tidak hadir pada diri individu (Miller \& Thoresen, 2003). Menurut Koenig, King, dan Hall (dalam Koenig, 2010), spiritualitas mencakup pencarian individu terhadap hal-hal transenden, sehingga melibatkan perjalanan panjang dari keadaan tidak adanya kepercayaan, mulai mempertanyakan, mulai memercayai, mulai mengabdi, hingga melakukan penyerahan diri. Fontana (2003) menambahkan bahwa melalui sudut pandang psikologis, spiritualitas dapat dipahami berdasarkan tampilan yang dapat diamati, seperti praktik spiritualitas, perilaku yang didasari oleh spiritualitas, dan pemikiran mengenai spiritualitas. 
Menurut Underwood dan Teresi (2002), spiritualitas terbagi menjadi dua aspek, yaitu persepsi tentang adanya sesuatu yang bersifat transenden dan persepsi tentang peristiwa transenden. Aspek persepsi tentang adanya sesuatu yang bersifat transenden mengacu kepada persepsi seseorang mengenai keberadaan hal-hal yang bersifat transenden dalam kehidupannya, seperti Tuhan. Seseorang yang merasakan adanya kehadiran Tuhan dapat merasakan bimbingan, bantuan, kasih sayang, dan berkah yang diberikan oleh-Nya, sehingga dapat mengalihkan kekhawatirannya dalam kehidupan sehari-hari. Ibu hamil yang memiliki aspek tersebut diprediksi cenderung merasakan adanya bantuan serta kasih sayang yang diberikan oleh Tuhan atau hal-hal transenden lainnya selama masa kehamilannya.

Sementara itu, persepsi tentang peristiwa transenden mengacu kepada persepsi seseorang mengenai pengaruh hubungannya dengan hal-hal yang bersifat transenden terhadap peristiwa yang terjadi di kehidupannya. Seseorang yang memiliki hubungan yang dekat dengan Tuhan dapat merasakan kekuatan, kenyamanan, kedamaian batin, serta kasih sayang dari lingkungannya seharihari. Ibu hamil yang memiliki aspek tersebut diprediksi cenderung menjalani masa kehamilannya dengan perasaan nyaman dan damai. Ia juga merasakan adanya kasih sayang yang diberikan oleh orang-orang di sekitarnya.

\section{Depresi}

Menurut Spitzer, Endicott, dan Robins (1978), depresi merupakan suatu gangguan yang menyebabkan hilangnya minat dan rasa senang seseorang terhadap suatu hal. Jika seseorang mengalaminya selama seminggu atau lebih, maka ia memiliki indikasi depresi. Selain itu, American Psychiatric Association (APA) (2000) dalam DSM-IV-TR menjelaskan bahwa depresi dapat diklasifikasikan sebagai suatu gangguan suasana perasaan. Seseorang yang mengalami depresi akan diliputi perasaan depresi, seperti sedih, hampa, dan putus asa atau kehilangan minat dalam berbagai aktivitas selama dua minggu atau lebih.

Menurut Oltmanns dan Emery (2013), gejala-gejala depresi terbagi menjadi empat bidang umum, yaitu gejala emosional, kognitif, somatik, dan perilaku. Gejala emosional umumnya berupa persaan muram, sedih, putus asa, dan cemas. Ibu hamil juga dapat mengalami gejala emosional berupa kemarahan, ketegangan, gugup, hingga kecemasan (Affonso dkk., 1992). sedangkan, gejala kognitif yang dialami adalah pikiran melamban, sulit berkonsentrasi, mudah terdistraksi dan menyalahkan dirinya, serta perubahan pada cara berpikir terhadap dirinya dan sekitarnya. Selain itu, gejala somatik juga dapat dialami oleh orang yang mengalami depresi, seperti kelelahan, sakit, 
nyeri, serta perubahan dalam nafsu makan dan pola tidur. Namun, perubahan nafsu makan dan pola tidur umumnya banyak terjadi pada ibu hamil sehingga gejala tersebut tidak dapat menjadi indikasi depresi pada masa kehamilan (Marcus, 2009). Selain itu, terdapat pula gejala perilaku yang umumnya dialami oleh penderita depresi, seperti gerakan melambat, cara bicara atau berjalan yang melambat, hingga tidak dapat bergerak sama sekali dan berhenti bicara (Oltmanns \& Emery, 2013).

\section{METODE}

\section{Partisipan}

Sampel penelitian ini diperoleh dengan menggunakan teknik pengambilan sampel secara sengaja (purposive sampling). Jumlah sampel adalah 125 orang ibu hamil $\left(M_{\text {usia }}=27.92 ; S D=\right.$ 5.06) dengan karakteristik berusia 18 tahun atau lebih, serta memiliki tempat tinggal di wilayah Jakarta, Bogor Depok, Tangerang, atau Bekasi. Sebanyak 119 sampel diperoleh melalui penyebaran kuesioner secara fisik dan sebanyak 6 sampel diperoleh melalui penyebaran kuesioner secara online.

\section{Desain}

Desain penelitian ini adalah penelitian korelasional dengan menggunakan analisis regresi. Penelitian ini bertujuan untuk menguji seberapa jauh perubahan nilai variabel kriteria jika nilai variabel prediktor dimanipulasi atau dinaik-turunkan (Sugiyono, 2010).

\section{Prosedur}

Alat ukur yang digunakan untuk mengukur depresi pada penelitian ini adalah Edinburgh Postnatal Depression Scale (EPDS) yang dikembangkan oleh Cox, Holden, dan Sagovsky (1987). Alat ukur ini terdiri dari 10 butir (tujuh butir favorable dan tiga butir unfavorable). Pilihan jawaban terbagi menjadi empat yang bervariasi pada tiap-tiap butirnya dan menggunakan skala Likert (0 3). Skor cut-off depresi yang umumnya digunakan adalah 12, di mana seseorang yang memiliki total skor depresi di atas 12 memiliki kemungkinan menderita depresi dan memerlukan penegakan diagnosis lebih lanjut. EPDS memiliki reliabilitas sebesar .834 dan validitas pada masing-masing butir sebesar .239 sampai .734 . 
Alat ukur yang digunakan untuk mengukur self-compassion adalah Self-Compassion Scale (SCS) yang telah diadaptasi ke dalam bahasa Indonesia oleh Febrinabilah (2016). Alat ukur SelfCompassion Scale (SCS) terdiri dari enam aspek dengan total sebanyak 26 butir, yaitu aspek selfkindness (5 butir favorable), self-judgement (5 butir unfavorable), common humanity (4 butir favorable), isolation (4 butir unfavorable), mindfulness (4 butir favorable), dan over-identification (4 butir unfavorable). Selain itu, alat ukur tersebut terdiri dari lima pilihan jawaban dan menggunakan skala Likert $(1-5)$. SCS memiliki reliabilitas yang baik sebesar 920 dan validitas masing-masing butir sebesar .385 sampai .719.

Selain itu, spiritualitas diukur menggunakan alat ukur Daily Spiritual Experience Scale (DSES) yang dikembangkan oleh Underwood dan Teresi (2002). DSES terdiri dari dua aspek dengan total sebanyak 16 butir, yaitu aspek persepsi tentang adanya sesuatu yang bersifat transenden ( 8 butir favorable) dan aspek persepsi tentang peristiwa transenden ( 8 butir favorable). Kemudian, alat ukur ini juga terdiri dari enam pilihan jawaban dan menggunakan skala Likert (1 6). Khusus pada butir terakhir, terdapat empat pilihan jawaban yang berbeda dari pilihan jawaban pada butir-butir sebelumnya dan menggunakan skala Likert (1 - 4). DSES memiliki reliabilitas sebesar .884 dan validitas tiap butir sebesar .231 sampai .796. Perhitungan self-compassion pada penelitian ini dilakukan melalui skor total yang diperoleh masing-masing responden penelitian.

\section{Teknik Analisis}

Dalam penelitian ini, dilakukan analisis regresi ganda dengan metode enter menggunakan SPSS for Windows 20.0. Kemudian, dilakukan uji beda sebagai hasil tambahan dalam penelitian.

\section{ANALISIS DAN HASIL}

Jumlah responden yang diperoleh dalam penelitian ini adalah sebanyak 125 orang, yaitu ibu hamil yang berusia di atas 18 tahun, memiliki tempat tinggal di wilayah Jakarta, Bogor, Depok, Tangerang, dan Bekasi, serta bersedia untuk mengisi kuesioner yang telah diberikan. Berikut merupakan gambaran data demografi responden yang diperoleh dalam penelitian ini. 
Tabel 1.

Data Demografi

\begin{tabular}{lll}
\hline \multicolumn{1}{c}{ VARIABEL } & $\boldsymbol{n}$ & $\boldsymbol{\%}$ \\
\hline USIA $(M=27.92 ; S D=5.06)$ & & \\
$19-25$ & 35 & 28 \\
$26-32$ & 72 & 57.6 \\
$33-39$ & 16 & 12.8 \\
$40-46$ & 2 & 1.6 \\
\hline DOMISILI & & \\
Jakarta & 88 & 70.4 \\
Bogor & 5 & 4 \\
Depok & 9 & 7.2 \\
Tangerang & 3 & 2.4 \\
Bekasi & 20 & 16 \\
\hline PENDIDIKAN & & \\
SD & 4 & 3.2 \\
SMP & 9 & 7.2 \\
SMA & 36 & 28.8 \\
D1 & 4 & 3.2 \\
D3 & 23 & 18.4 \\
S1 & 43 & 34.4 \\
S2 & 6 & 4.8 \\
& & \\
\hline
\end{tabular}

\begin{tabular}{lcc}
\hline \multicolumn{1}{c}{ VARIABEL } & $\boldsymbol{n}$ & $\boldsymbol{\%}$ \\
\hline PENGHASILAN & & \\
< Rp. 1.000 .000 & 6 & 4.8 \\
Rp. $1.000 .000-$ Rp. 3.000 .000 & 25 & 20 \\
Rp. $3.000 .000-$ Rp. 5.000 .000 & 38 & 30.4 \\
Rp. $5.000 .000-$ Rp. 7.000 .000 & 24 & 19.2 \\
> Rp. 7.000.000 & 32 & 25.6 \\
\hline STATUS PERNIKAHAN & & \\
Menikah (Pernikahan Pertama) & 121 & 96.8 \\
Menikah Kembali & 4 & 3.2 \\
\hline STATUS KEHAMILAN & & \\
Pertama & 67 & 53.6 \\
Kedua & 40 & 32 \\
Lainnya & 18 & 14.4 \\
\hline USIA KEHAMILAN & & \\
Trimester ke-1 & 16 & 12.8 \\
Trimester ke-2 & 53 & 42.4 \\
Trimester ke-3 & 56 & 44.8 \\
\hline PENGALAMAN KEGUGURAN & & \\
Ya & 9 & 7.2 \\
Tidak & 116 & 92.8 \\
\hline
\end{tabular}

Sebelum melakukan analisis regresi ganda, dilakukan uji korelasi terlebih dahulu sebagai syarat dilakukannya analisis regresi. Dari uji korelasi didapatkan hasil bahwa terdapat hubungan negatif yang signifikan antara self-compassion dan depresi $(r=-.552 ; p<.01)$. Selain itu, terdapat juga hubungan negatif yang signifikan antara spiritualitas dan depresi $(r=-.462 ; p<.01)$. Kemudian, dilakukan analisis regresi ganda dan ditemukan bahwa terdapat peranan antara selfcompassion dan spiritualitas secara bersama-sama terhadap depresi pada ibu hamil $\left(R^{2}=.408\right.$; $p=.000)$. Hal tersebut menunjukkan bahwa variabel self-compassion dan spiritualitas secara bersama memiliki kontribusi sebesar 40.8 persen terhadap variabel depresi dan sebesar 59.2 persen dipengaruhi oleh faktor lain.

Selanjutnya, dilakukan uji korelasi semi-parsial untuk melihat besar kontribusi unik pada peranan self-compassion terhadap depresi terlepas dari peran spiritualitas, dan sebaliknya. Hasil yang didapatkan menunjukkan bahwa self-compassion memiliki kontribusi sebesar 19.4 persen terhadap depresi, sedangkan spiritualitas memiliki kontribusi sebesar 10.3 persen. Selain itu, dilakukan juga uji korelasi semi-parsial terhadap tiap-tiap aspek yang terdapat pada self-compassion dan spiritualitas. Berikut hasil yang didapatkan. 
Tabel 2.

Hasil Uji Korelasi Semi-Parsial Per-Aspek

\begin{tabular}{ccccccccc}
\hline & SCSsk $^{*}$ & SCSsj $^{*}$ & SCSch $^{*}$ & SCSi $^{*}$ & SCSm $^{*}$ & SCSoi $^{*}$ & DSESbt $^{*}$ & DSESpt $^{*}$ \\
\hline S & .004 & .019 & .000 & .002 & .000 & .018 & .009 & .019 \\
Sig. & .385 & $.048^{* *}$ & .749 & .491 & .845 & .056 & .183 & $.047^{* * *}$ \\
\hline
\end{tabular}

Keterangan: SCSsk $=$ self-kindness, $\mathbf{S C S s j}=$ self-judgement, $\mathbf{S C S c h}=$ common humanity, $\mathbf{S C S i}=$ isolation, $\mathbf{S C S m}=$ mindfulness, $\mathbf{S C S o i}=$ over-identification, $\mathbf{D S E S b t}=$ persepsi tentang adanya sesuatu yang bersifat transenden, DSESpt $=$ persepsi tentang peristiwa transenden

** Signifikan pada tingkat .05

Berdasarkan data yang terdapat pada tabel 2, uji korelasi semi-parsial pada masing-masing aspek self-compassion dan spiritualitas menunjukkan bahwa aspek self-judgement dan persepsi tentang peristiwa transenden (DSESpt) memiliki pengaruh signifikan terhadap depresi, di mana masing-masing aspek menghasilkan besaran koefisien korelasi yang sama, yaitu sebesar .019 $p$ < $.05)$.

Dalam penelitian ini, dilakukan analisis tambahan untuk melihat perbedaan skor depresi pada kelompok-kelompok responden yang dikategorikan berdasarkan faktor-faktor demografi yang secara teoretis memiliki peran terhadap variabel tersebut. Berikut hasil yang didapatkan:

Tabel 3.

Hasil Uji Beda

\begin{tabular}{lll}
\hline \multicolumn{1}{c}{ Variabel } & \multicolumn{1}{c}{ F } & Sig. \\
\hline Usia & 1.474 & .225 \\
Pendidikan & .850 & .534 \\
Penghasilan & .931 & .449 \\
Usia Kehamilan & 1.699 & .187 \\
Pengalaman Keguguran .609 & .436 \\
\hline
\end{tabular}

Berdasarkan data yang terdapat pada tabel 3 di atas, tidak terdapat perbedaan depresi yang signifikan pada antar kelompok responden jika ditinjau dari faktor usia, pendidikan, penghasilan, usia kehamilan, maupun pengalaman keguguran responden.

\section{DISKUSI}

Berdasarkan uji regresi ganda yang dilakukan, diperoleh hasil bahwa self-compassion dan spiritualitas berperan secara bersama-sama dan signifikan terhadap depresi pada ibu hamil $(p<.05)$. Hal tersebut menunjukkan bahwa semakin tinggi self-compassion dan spiritualitas yang dimiliki 
oleh ibu hamil, maka semakin berpengaruh terhadap penurunan depresi yang dimilikinya, sehingga hipotesis yang diajukan oleh peneliti dapat diterima. Hasil penelitian tersebut memberikan wawasan baru mengenai keterkaitan antar kedua variabel tersebut dalam memengaruhi depresi sebesar 40.8 persen dan sebanyak 59.2 persen sisanya dipengaruhi oleh faktor lain di luar kedua variabel tersebut. Pada peranan tersebut, self-compassion ditemukan memiliki kontribusi unik yang lebih besar dibandingkan dengan spiritualitas.

Berdasarkan uji regresi yang dilakukan, diperoleh hasil bahwa self-compassion berperan secara signifikan terhadap depresi pada ibu hamil. Hal tersebut menunjukkan bahwa semakin tinggi self-compassion yang dimiliki oleh ibu hamil, maka semakin berpengaruh terhadap penurunan depresi yang dimilikinya. Hasil penelitian tersebut mendukung hasil penelitian sebelumnya bahwa self-compassion merupakan variabel prediktor yang dapat memprediksi gejala dan kualitas hidup secara kuat, salah satunya terhadap depresi (Van Dam, Sheppard, Forsyth, \& Earleywine, 2011).

Peran self-compassion terhadap depresi tersebut disebabkan oleh adanya variabel lain, yaitu ruminasi (Raes, 2010; Krieger, Altenstein, Baettig, Doerig, \& Holtforth, 2013). Ruminasi adalah perilaku berpikir secara berulang dan evaluasi secara abstrak terhadap diri dan suatu hal yang sudah terjadi (Leary, Tate, Adams, Allen, \& Hancock, 2007). Ruminasi terbukti dapat memperpanjang dan memperdalam rasa sedih dan mood depresi. Self-compassion menekankan adanya perasaan terbuka terhadap kesulitan dan memahami kegagalan yang sedang dialami. Dari penelitian sebelumnya, ditemukan bahwa seseorang yang memiliki self-compassion tinggi cenderung rendah untuk mengalami efek negatif dari pengalaman negatif karena memiliki ruminasi yang rendah. Oleh karena itu, self-compassion memungkinkan individu untuk menghadapi situasi negatif tanpa terlarut dalam emosi-emosi negatif yang dirasakan atau melakukan ruminasi, sehingga individu memiliki kecenderungan yang lebih rendah untuk mengalami depresi (Leary dkk., 2007; Raes, 2010). Dengan demikian, peningkatan self-compassion dapat berpengaruh terhadap penurunan depresi.

Pada uji korelasi semi-parsial terhadap masing-masing aspek self-compassion, ditemukan bahwa hanya aspek self-judgement yang memiliki pengaruh signifikan terhadap depresi. Hal tersebut sejalan dengan penelitian yang dilakukan oleh Van Dam dkk. (2011) bahwa aspek selfjudgement dan isolation memiliki peran yang signifikan dalam memprediksi kecemasan, depresi, kekhawatiran, dan kualitas hidup. Hal tersebut disebabkan oleh adanya hubungan antara selfjudgement dan ruminasi yang berfokus pada diri sendiri sehingga dapat meningkatkan depresi (Rimes \& Watkins, 2005). Dengan kata lain, seseorang yang memiliki self-judgement rendah cenderung mempunyai tingkat depresi yang rendah juga. 
Self-judgement secara konsep merupakan aspek yang berlawanan dengan aspek selfkindness (Neff, 2003a). Akan tetapi, Neff (2003a) menambahkan bahwa aspek tersebut juga dapat memengaruhi aspek lainnya. Jika seseorang berhenti menghakimi diri sendiri (self-judgement), maka ia telah menunjukkan adanya kelembutan pada diri sendiri (self-kindness). Hal ini dapat mengurangi dampak pengalaman emosional yang negatif yang berlebihan (over-identification) dan dapat mempermudah seseorang dalam menjaga kesadaran terhadap pikiran dan emosi yang dirasakan secara seimbang (mindfulness).

Selain itu, menyadari bahwa kegagalan merupakan pengalaman yang umumnya dirasakan oleh orang lain (common humanity) dapat mengurangi kecenderungan seseorang untuk menyalahkan dan bersikap keras terhadap diri sendiri (self-judgement), sehingga dapat mengurangi adanya perasaan terisolasi (isolation). Berdasarkan penjelasan tersebut, dapat disimpulkan bahwa aspek self-judgement memiliki keterkaitan dengan aspek-aspek self-compassion lainnya, meskipun aspek-aspek tersebut tidak secara signifikan berpengaruh terhadap penurunan depresi. Seseorang yang memiliki aspek self-judgement rendahakan memiliki aspek isolation dan over-identification yang rendah, serta aspek self-kindness, common humanity, dan mindfulness yang tinggi, di mana hal tersebut berpengaruh terhadap penurunan depresi.

Hasil uji regresi juga menunjukkan bahwa spiritualitas berperan secara signifikan terhadap depresi pada ibu hamil. Hal tersebut menunjukkan bahwa semakin tinggi spiritualitas yang dimiliki oleh ibu hamil, maka semakin berpengaruh terhadap penurunan depresi yang dimilikinya. Hasil penelitian tersebut memberikan temuan tambahan dari hasil penelitian sebelumnya yang menunjukkan bahwa terdapat korelasi negatif yang signifikan antara spiritualitas dan depresi (Koenig, 2010; Mann dkk., 2007; Nelson dkk., 2009). Dari hasil penelitian ini, ditemukan bahwa spiritualitas bukan hanya memiliki hubungan negatif terhadap depresi, tetapi juga memiliki kontribusi yang signifikan dalam penurunan depresi.

Pada penelitian sebelumnya, ditemukan bahwa spiritualitas memiliki peranan terhadap ibu hamil yang memiliki gejala depresi (Mann, McKeown, Bacon, Vesselinov, \& Bush, 2007). Spiritualitas membantu individu menemukan arti dari situasi yang penuh tekanan (stressful) dan membantu individu melewati situasi tersebut. Pada penelitian yang dilakukan oleh Krok (2008), ditemukan bahwa individu dengan tingkat spiritualitas yang tinggi cenderung mengandalkan sumber-sumber spiritual yang dimiliki ketika menghadapi stres dan cenderung dapat mengendalikan proses kognitif dan emosinya. Spiritualitas menjadi faktor protektif bagi individu dan berperan 
dalam penurunan depresi (Staton-Tindall, Duvall, Stevens-Watkins, \& Oser, 2013). Oleh karena itu, peningkatan spiritualitas dapat berpengaruh terhadap penurunan depresi.

Pada uji korelasi semi-parsial terhadap masing-masing aspek spiritualitas, ditemukan bahwa hanya aspek persepsi tentang peristiwa transenden yang memiliki pengaruh signifikan terhadap depresi. Peneliti belum menemukan hasil penelitian lain yang melihat aspek-aspek spiritualitas dan peran dari masing-masing aspek tersebut terhadap depresi. Oleh karena itu, peneliti memiliki asumsi bahwa terdapat keterkaitan aspek persepsi tentang peristiwa transenden dengan spiritual coping. Menurut Underwood dan Teresi (2002), aspek persepsi tentang peristiwa transenden merupakan adanya keyakinan bahwa individu memiliki interaksi dengan sesuatu yang bersifat transenden dalam kehidupan sehari-hari. Dengan demikian, jika seseorang menghadapi situasi sulit atau gagal dalam hal-hal tertentu, maka ia cenderung mempersepsikan peristiwa tersebut sebagai sesuatu yang telah ditetapkan oleh transenden atau dapat diasosiasikan sebagai Tuhan. Hal tersebut termasuk dalam spiritual coping yang dapat membantu seseorang dalam mengendalikan proses kognitif dan emosi yang negatif sehingga berpengaruh terhadap penurunan depresi.

Berdasarkan uji korelasi yang dilakukan, diperoleh hasil bahwa terdapat korelasi yang signifikan antara self-compassion dan spiritualitas pada ibu hamil. Hal tersebut menunjukkan bahwa kedua variabel prediktor memiliki hubungan satu sama lain. Semakin tinggi self-compassion yang dimiliki ibu hamil, maka semakin tinggi pula spiritualitas yang dimilikinya, begitu juga sebaliknya. Hasil penelitian tersebut sejalan dengan hasil penelitian sebelumnya, yaitu pada penelitian yang dilakukan oleh Birnie dkk. (2010) bahwa self-compassion memiliki hubungan positif yang signifikan dengan spiritualitas pada sampel dewasa.

Hasil serupa ditemukan pula pada penelitian yang dilakukan oleh Akin dan Akin (2015) pada sampel mahasiswa di Universitas Turki. Jika dibandingkan dengan sampel yang digunakan dalam penelitian ini, yaitu ibu hamil, maka dapat disimpulkan bahwa tidak terdapat perbedaan hubungan antara self-compassion dan spiritualitas pada karakteristik sampel yang berbeda. Selain itu, individu yang meyakini adanya belas kasih yang diberikan oleh Tuhan memiliki kemungkinan untuk merefleksikan keyakinan tersebut kepada dirinya sendiri, yaitu dengan memberikan kelembutan pada diri sendiri yang merupakan salah satu aspek dari self-compassion (Neff, 2003b).

Berdasarkan hasil pengukuran depresi terhadap sampel penelitian, diketahui bahwa sebanyak 41 orang atau 32.8 persen dari 125 orang total sampel memiliki indikasi depresi. Hasil tersebut menunjukkan bahwa prevalensi depresi pada ibu hamil pada penelitian ini diprediksi lebih tinggi dibandingkan dengan prevalensi pada penelitian Gavin dkk. (2005), yaitu sebanyak 6.5 
persen hingga 12.9 persen. Berdasarkan uji beda yang dilakukan, diperoleh hasil bahwa tidak terdapat perbedaan depresi yang signifikan pada antar kelompok responden jika ditinjau dari faktor usia, pendidikan, penghasilan, usia kehamilan, maupun pengalaman keguguran responden. Hasil tersebut dapat dipengaruhi oleh penyebaran sampel yang belum merata pada antar kelompok.

Temuan utama dalam penelitian ini menunjukkan bahwa peningkatan self-compassion dan spiritualitas berpengaruh terhadap penurunan depresi yang dapat dialami oleh ibu hamil, di mana integrasi antara self-compassion dan spiritualitas terhadap depresi belum pernah diteliti sebelumnya. Oleh karena itu, hasil tersebut dapat dijadikan tambahan informasi dan rujukan dalam menangani permasalahan depresi pada ibu hamil. Hasil penelitian yang terdapat dalam penelitian ini secara umum telah memberikan tambahan data dan wawasan baru mengenai self-compassion, spiritualitas, dan depresi, khususnya pada ibu hamil, sehingga perlu diteliti lebih lanjut secara mendalam pada penelitian selanjutnya.

Secara keseluruhan, penelitian ini masih memiliki beberapa kekurangan dan keterbatasan. Penyebaran sampel pada penelitian ini masih belum merata, baik berdasarkan rentang usia, domisili, maupun penghasilan. Mayoritas sampel dalam penelitian ini berasal dari wilayah Jakarta (70.4\%) dan memiliki tingkat penghasilan menengah ke atas (75.2\%), sehingga hasil penelitian ini kurang menggambarkan ibu hamil yang berada di wilayah Jakarta, Bogor, Tangerang, Bekasi, dan Depok dengan berbagai tingkat sosio-ekonomi secara menyeluruh. Selain itu, penelitian ini belum mempertimbangkan faktor-faktor lain yang turut berperan terhadap depresi pada ibu hamil, seperti kualitas hubungan ibu hamil dengan pasangannya. Penelitian sebelumnya menunjukkan bahwa dukungan yang diberikan oleh pasangan ibu hamil berkorelasi dengan rendahnya tingkat depresi selama masa kehamilan (Pajulo dkk., 2001). Namun, penelitian ini pun belum menggambarkan kondisi pasangan ibu hamil, di mana pada penelitian Boyce, Condon, Barton, dan Corkindale (2007) diketahui bahwa calon ayah turut mengalami tekanan secara psikologis (psychological distress) selama masa kehamilan pasangannya.

\section{SIMPULAN DAN SARAN}

\section{Simpulan}

Berdasarkan analisis yang dilakukan, dapat disimpulkan bahwa hipotesis yang diajukan pada penelitian ini dapat diterima, yaitu self-compassion dan spiritualitas secara signifikan berperan 
terhadap depresi pada ibu hamil, yaitu sebesar 40.8 persen. Self-compassion memberikan kontribusi unik sebesar 19.4 persen, di mana hanya aspek self-judgement yang memiliki peran terhadap depresi secara signifikan. Sementara itu, spiritualitas memberikan kontribusi unik sebesar 10.3 persen, di mana hanya aspek persepsi mengenai peristiwa transenden yang memiliki peran terhadap depresi secara signifikan.

\section{Saran Teoretis}

Penelitian selanjutnya diharapkan dapat menghubungkan faktor lain yang diduga turut berperan terhadap depresi pada ibu hamil. Faktor tersebut dapat berupa kualitas hubungan ibu hamil dengan pasangannya, seperti halnya peran dukungan pasangan terhadap depresi pada ibu hamil. Kemudian, penelitian selanjutnya diharapkan juga menggunakan sampel pasangan ibu hamil yang diduga turut mengalami depresi selama masa kehamilan pasangannya. Selain itu, sampel yang diperoleh disarankan memiliki penyebaran wilayah serta tingkat sosio-ekonomi yang lebih beragam agar mendapatkan hasil yang lebih menyeluruh.

\section{Saran Praktis}

Bagi para ibu yang sedang hamil disarankan untuk meningkatkan self-compassion dan spiritualitas agar terhindar dari depresi selama masa kehamilan. Upaya yang dapat dilakukan adalah dengan mengurangi sikap mengkritik diri secara berlebihan, menyadari bahwa kesulitan yang dialami selama masa kehamilan merupakan hal yang wajar, serta berusaha menjaga pikiran dan perasaan yang dimiliki secara seimbang. Para ibu hamil juga dapat mengikuti pelatihan selfcompassion maupun mindfulness, serta menggunakan pendekatan spiritualitas ketika sedang mengalami hal yang sulit.

Bagi psikolog yang memiliki keahlian dalam terapi yang menggunakan pendekatan selfcompassion maupun mindfulness, seperti mindful self-compassion (MSC) atau mindfulness-based cognitive therapy (MBCT), dapat memberikan pelatihan tersebut kepada ibu hamil agar dapat meningkatkan self-compassion maupun spiritualitas sehingga terhindar dari depresi, khususnya selama masa kehamilan. 


\section{CATATAN}

Sebagian dari hasil penelitian ini telah dipresentasikan pada Asia International Multidisciplinary Conference (AIMC) pada tanggal 1-2 Mei 2017 di Kuala Lumpur, Malaysia.

\section{REFERENSI}

Affonso, D. D., Lovett, S., Paul, S., Sheptak, S., Nussbaum, R., Newman, L., \& Johnson, B. (1992). Dysphoric distress in childbearing women. Journal of Perinatology, 12(4),325-332.

Akin, A., \& Akin, U. (2015). Does self-compassion predict spiritual experiences of Turkish university students? Journal of Religion and Health, 56(1), 109-117. doi: 10.1007/s10943015-0138-y

American Psychiatric Association. (2000). DSM-IV-TR: Diagnostic and statistical manual of mental disorders (4th ed., Text Revision). Washington, DC: American Psychiatric Association Publishing.

Bennet, H. A., Einarson, A., Taddio, A., Koren, G., \& Einarson T. R. (2004). Prevalence of depression during pregnancy: Systematic review. Obstetrics \& Gynecology, 103(4), 698-709. doi: 10.1097/01.AOG.0000116689.75396.5f

Bento, E., Xavier, S., Azevedo, J., Marques, M., Soares, M. J., Martins, M. J., ...\& Pereira, A. T. (2016). The role of self-compassion in lifetime history of depression: A study in Portuguese pregnant women. Journal of European Psychiatry, 33. 416-417. doi: 10.1016/j.eurpsy.2016.01.1507

Birndorf, C. A., Madden, A., Portera, L., \& Leon, A. C. (2001). Psychiatric symptoms, functional impairment, and receptivity toward mental health treatment among obstetrical patients. The International Journal of Psychiatry in Medicine, 31(4), 355-365. doi: 10.2190/5vpd-wgl1mtwn-6ja6

Birnie, K., Speca, M., \& Carlson, L. E. (2010). Exploring self-compassion and empathy in the context of mindfulness-based stress reduction (MBSR). Stress and Health: Journal of the International Society for the Investigation of Stress, 26(5), 359-371. doi: 10.1002/smi.1305

Boscaglia, N., Clarke, D. M., Jobling, T. W., \& Quinn, M. A. (2005). The contribution of spirituality and spiritual coping to anxiety and depression in women with a recent diagnosis 
of gynecological cancer. International Journal of Gynecological Cancer, 15(5), 755-761. doi: 10.1111/j.1525-1438.2005.00248.x

Boyce, P., Condon, J., Barton, J., \& Corkindale, C. (2007). First-time fathers'study: Psychological distress in expectant fathers during pregnancy. Australian \& New Zealand Journal of Psychiatry, 41(9), 718-725. doi: 10.1080/00048670701517959

Brown, J. E., \& Toma, R. B. (1986). Taste changes during pregnancy. The American Journal of Clinical Nutrition, 43(3), 414-418. doi: 10.1093/ajcn/43.3.414

Carver, C. S., \& Gaines, J. G. (1987). Optimism, pessimism, and postpartum depression. Cognitive Therapy and Research, 11(4), 449-462.

Cox, J. L., Holden, J. M., \& Sagovsky, R. (1987). Detection of postnatal depression: Development of the 10-item Edinburgh Postnatal Depression Scale (EPDS). The British Journal of Psychiatry, 150(6), 782-786. doi: 10.1192/bjp.150.6.782

Dinn, R. B., Harris, A., \& Marcus, P. S. (2003). Ocular changes in pregnancy. Obstetrical \& Gynecological Survey, 58(2), 137-144. doi: 10.1097/01.OGX.0000047741.79433.52

Dumont, M., \& Provost, M. A. (1999). Resilience in adolescents: Protective role of social support, coping strategies, self-esteem, and social activities on experience of stress and depression. Journal of Youth and Adolescence, 28(3), 343-363. doi: 10.1023/a:1021637011732

Ellison, C. W. (1983). Spiritual well-being: Conceptualization and measurement. Journal of Psychology and Theology, 11(4), 330-340. doi: 10.1177/009164718301100406

Evans, J., Heron, J., Francomb, H., Oke, S., \& Golding, J. (2001). Cohort study of depressed mood during pregnancy and after childbirth. British Medical Journal, 323(7307), 257-260. doi: 10.1136/bmj.323.7307.257

Febrinabilah, R. (2016). Hubungan antara self-compassion dengan resiliensi pada mantan pecandu narkoba dewasa awal (Skripsi yang tidak dipublikasikan). Fakultas Psikologi Universitas YARSI Jakarta, Indonesia.

Felder, J. N., Lemon, E., Shea, K., Kripke, K., \& Dimidjian, S. (2016). Role of self-compassion in psychological well-being among perinatal women. Archives Women's Mental Health, 19(4), 687-690. doi: 10.1007/s00737-016-0628-2

Fontana, D. (2003). Psychology, religion, and spirituality. Malden, MA: BPS Blackwell.

Gavin, N. I., Gaynes, B. N., Lohr, K. N., Meltzer-Brody, S., Gartlehner, G., \& Swinson, T. (2005). Perinatal depression: A systematic review of prevalence and incidence. Obstetrics and Gynecology, 106(5), 1071-1083. doi: 10.1097/01.AOG.0000183597.31630.db 
Gilbert, P., \& Procter, S. (2006). Compassionate mind training for people with high shame and selfcriticism: Overview and pilot study of a group therapy approach. Clinical Psychology \& Psychotherapy, 13(6), 353-379. doi: 10.1002/cpp.507

Goodenough, U. (2001). Vertical and horizontal transcendence. Zygon, 36(1), 21-31. doi: 10.1111/0591-2385.00337

Grote, N. K., Bridge, J. A., Gavin, A. R., Melville, J. L., Iyengar, S., \& Katon, W. J. (2010). A meta-analysis of depression during pregnancy and the risk of preterm birth, low birth weight, and intrauterine growth restriction. Arch Gen Psychiatry, 67(10), 1012-1024. doi: 10.1001/archgenpsychiatry.2010.111

Hayes, B. A., Muller, R., \& Bradley, B. S. (2001). Perinatal depression: A randomized control trial of an antenatal education intervention for primiparas. Birth, 28(1), 28-35. doi: 10.1046/j.1523536x.2001.00028.x

Jesse, D. E., Schoneboom, C., \& Blanchard, A. (2007). The effect of faith or spirituality in pregnancy. Journal of Holistic Nursing, 25(3), 151-158. doi: 10.1177/0898010106293593

Josefsson, A., Berg, G., Nordin, C., \& Sydsjö, G. (2001). Prevalence of depressive symptoms in late pregnancy and postpartum. Acta Obstetricia et Gynecologica Scandinavica, 80(3), 251-255. doi: 10.1034/j.1600-0412.2001.080003251.x

Karacam, Z., \& Ancel, G. (2009). Depression, anxiety and influencing factors in pregnancy: A study in a Turkish population. Midwifery, 25(4), 344-356. doi: 10.1016/j.midw.2007.03.006

King, P. E. (2003). Religion and identity: The role of ideological, social, and spiritual contexts. Applied Developmental Science, 7(3), 197-204. doi: 10.1207/S1532480XADS0703_11

Koenig, H. G. (2010). Spirituality and mental health. International Journal of Applied Psychoanalytic Studies, 7(2), 116-122. doi: 10.1002/aps.239

Krieger, T., Altenstein, D., Baettig, I., Doerig, N., \& Holtforth, M. G. (2013). Self-compassion in depression: Associations with depressive symptoms, rumination, and avoidance in depressed outpatients. Behavior Therapy, 44(3), 501-513. doi: 10.1016/j.beth.2013.04.004

Kroelinger, C. D., \& Oths, K. S. (2000). Partner support and pregnancy wantedness. Birth, 27(2), 112-119. doi: 10.1046/j.1523-536x.2000.00112.x

Krok, D. (2008). The role of spirituality in coping: Examining the relationships between spiritual dimensions and coping styles. Mental Health, Religion \& Culture, 11(7), 643-653. doi: $10.1080 / 13674670801930429$ 
Krucik, G. (2012). How "baby" changes the body: See the power of pregnancy. Ditemu kembali dari dari https://www.healthline.com/health/pregnancy/body-changes-infographic\#1

Leary, M. R., Tate, E. B., Adams, C. E., Allen, A. B., \& Hancock, J. (2007). Self-compassion and reactions to unpleasant self-relevant events: The implications of treating oneself kindly. Journal of Personality and Social Psychology, 92(5), 887-904. doi: 10.1037/00223514.92.5.887

Luoma, I., Tamminen, T., Kaukonen, P., Laippala, P., Puura, K., Salmelin, R., \& Almqvist, F. (2001). Longitudinal study of maternal depressive symptoms and child well-being. Journal of the American Academy of Child Adolescent Psychiatry, 40(12), 1367-1374. doi: 10.1097/00004583-200112000-00006

Mann, J. R., Mckeown, R. E., Bacon, J., Vesselinov, R., \& Bush, F. (2007). Religiosity, spirituality, and depressive symptoms in pregnant women. The International Journal of Psychiatry in Medicine, 37(3), 301-313. doi: 10.2190/PM.37.3.g

Marcus, S. M. (2009). Depression during pregnancy: Rates, risks, and consequences. Can J Clin Pharmacol, 16(1), e15-e22.

Miller, W. R., \& Thoresen, C. E. (2003). Spirituality, religion, and health: An emerging research field. American Psychologist, 58(1), 24-35. doi: 10.1037/0003-066x.58.1.24

Neff, K. D. (2003a). The development and validation of a scale to measure self-compassion. Self and Identity, 2(3), 223-250. doi: 10.1080/15298860309027

Neff, K. D. (2003b). Self-compassion: An alternative conceptualization of a healthy attitude toward oneself. Self and Identity, 2(2), 85-101. doi: 10.1080/15298860390129863

Neff, K. D., Rude, S. S., \& Kirkpatrick, K. L. (2007). An examination of self-compassion in relation to positive psychological functioning and personality traits. Journal of Research in Personality, 41(4), 908-916. doi: 10.1016/j.jrp.2006.08.002

Nelson, C., Jacobson, C. M., Weinberger, M. I., Bhaskaran, V., Rosenfeld, B., Breitbart, W., \& Roth, A. J. (2009). The role of spirituality in the relationship between religiosity and depression in prostate cancer patients. Annals Behavioral Medicine, 38(2), 105-114. doi: 10.1007/s12160-009-9139-y

O’Hara, M. W. (1986). Social support, life events, and depression during pregnancy and the puerperium. Archives of General Psychiatry, 43(6), 569-573. doi: 10.1001/archpsyc.1986.01800060063008

Oltmanns, T. F., \& Emery, R. E. (2013). Psikologi abnormal. Yogyakarta: Pustaka Belajar. 
Pajulo, M., Savonlahti, E., Sourander, A., Helenius, H., \& Piha, J. (2001). Antenatal depression, substance dependency, and social support. Journal of Affective Disorders, 65(1), 9-17.

Raes, F. (2010). Rumination and worry as mediators of the relationship between self-compassion and depression and anxiety. Personality and Individual Differences, 48(6), 757-761. doi: 10.1016/j.paid.2010.01.023

Rasmussen, H. N., Wrosch, C., Scheier, M. F., \& Carver, C. S. (2006). Self-regulation processes and health: The importance of optimism and goal adjustment. Journal of Personality, 74(6), 1721-1748. doi: 10.1111/j.1467-6494.2006.00426.x

Rimes, K. A., \& Watkins, E. (2005). The effects of self-focused rumination on global negative selfjudgements in depression. Behaviour Research and Therapy, 43(12), 1673-1681. doi: 10.1016/j.brat.2004.12.002

Roomruangwong, C., \& Epperson, C. N. (2011). Perinatal depression in Asian women: Prevalence, associated factors, and cultural aspects. Asian Biomedicine, 5(2), 179-193. doi: 10.5372/1905-7415.0502.024

Ross, L. E., Sellers, E. M., Evans, S. E. G., \& Romach, M. K. (2004). Mood changes during pregnancy and the postpartum period: Development of a biopsychosocial model. Acta Psychiatrica Scandinavica, 109(6), 457-466. doi: 10.1111/j.1600-0047.2004.00296.x

Spitzer, R. L., Endicott, J., \& Robins, E. (1978). Research diagnostic criteria: Rationale and reliability. Archives of General Psychiatry, 373-782. doi:10.1001/archpsyc.1978.01770300115013

Staton-Tindall, M., Duvall, J., Stevens-Watkins, D., \& Oser, C. B. (2013). The role of spirituality in the relationship between traumatic life events, mental health, and drug use among African American women from one southern state. Substance Use \& Misuse, 48(12), 1246-1257. doi: 10.3109/10826084.2013.799023

Sugiyono. (2010). Metode penelitian kuantitatif, kualitatif, dan R\&D. Bandung: Penerbit Alfabeta.

Tunzi, M., \& Gray, G. R. (2007). Common skin conditions during pregnancy. American Family Physician, 75(2), 211-218.

Underwood, L. G., \& Teresi, J. A. (2002). The daily spiritual experience scale: Development, theoretical description, reliability, exploratory factor analysis, and preliminary construct validity using health-related data. Annals of Behavioral Medicine, 24(1), 22-33. doi: 10.1207/s15324796abm2401_04 
Van Dam, N. T., Sheppard, S. C., Forsyth, J. P., \& Earleywine, M. (2011). Self-compassion is a better predictor than mindfulness of symptom severity and quality of life in mixed anxiety and depression. Journal of Anxiety Disorders, 25(1), 123-130. doi: 10.1016/j.janxdis.2010.08.011

Wispe, L. (1991). The psychology of sympathy. New York, NY: Plenum Press. 